\title{
ASISTENSI PENGEMBANGAN MEDIA PEMBELAJARAN INTERAKTIF DENGAN AUTOPLAY UNTUK SISWA
}

\section{ASSISTANCE FOR THE DEVELOPMENT OF INTERACTIVE LEARNING MEDIA WITH AUTOPLAY FOR STUDENTS}

\author{
Primadya Anantyarta*, Dwi Candra Setiawan \\ Pendidikan Biologi, IKIP Budi Utomo Malang \\ Jl. Citandui 46, Malang \\ *Email: anantyarta@gmail.com \\ (Diterima 30-07-2021; Disetujui 23-08-2021)
}

\begin{abstract}
ABSTRAK
Belajar merupakan kebutuhan setiap insan. Pada masa pandemi covid-19 saat ini juga merubah kebiasaan belajar yang biasanya dilakukan secara tatap muka dalam satu ruangan, kini harus dilakukan secara online. Minimnya media pembelajaran yang dapat digunakan membantu siswa belajar secara mandiri karena pandemi saat ini, mendorong dilakukannya pendampingan bagi mahasiswa calon guru untuk mengembangkan media interaktif yang dapat digunakan untuk mengajar kelak. Pengembangan media pembelajaran interaktif tersebut dapat dilakukan dengan menggunakan suatu aplikasi yang dapat menggabungkan berbagai jenis file dalam satu media, baik berupa gambar, tulisan, dan video. Bahan yang diperlukan untuk mengembangkan media tersebut antara lain komputer atau laptop, jaringan internet untuk menambah kelengkapan komponen dalam mengembangkan media dan aplikasi bernama Autoplay Media Studio. Pendampingan dalam mengembangkan media ini dilakukan dengan metode ceramah, simulasi, praktik langsung dan evaluasi produk dari mahasiswa. Hasil dari pendampingan ini menunjukkan bahwa mahasiswa calon guru sangat antusias dan termotivasi dalam membuat produk. Selain semakin terampil, mahasiswa juga dapat terlatih dalam menerapkan pengkodean dalam mengatur konten media yang dibuat. Bahkan tercipta beberapa macam tema pada media pembelajaran yang dikembangkan.
\end{abstract}

Kata kunci: Pendampingan, Media Interaktif, Autoplay

\section{ABSTRACT}

Learning is the need of every human being. During the current covid-19 pandemic, learning habits, which are usually done face-to-face in one room, now have to be done online. The lack of learning media that can be used to help students learn independently due to the current pandemic, encourages mentoring for prospective teacher students to develop interactive media that can be used to teach in the future. The development of interactive learning media can be done by using an application that can combine various types of files in one media, either in the form of images, writings, and videos. The materials needed to develop the media include a computer or laptop, an internet network to add to the completeness of components in developing media and an application called Autoplay Media Studio. Assistance in developing this media is done by using lecture methods, simulations, direct practice and product evaluation from students. The results of this mentoring show that student teacher candidates are very enthusiastic and motivated in making products. In addition to being more skilled, students can also be trained in applying coding in managing media content that is created. Even created several kinds of themes in the learning media developed.

Keywords: Assistance, Interactive Media, Autoplay

\section{PENDAHULUAN}

Dunia pendidikan pasti tidak dapat dipisahkan dengan jenjang bagi siswa. Mulai dari taman kanak-kanak, pendidikan dasar, hingga perguruan tinggi. Pendidikan dasar ditempuh selama 6 tahun, pendidikan menengah selama 3 tahun, dan pendidikan tinggi selama 2-4 tahun (diploma), 4 tahun atau lebih (sarjana), dan 2 tahun atau lebih (magister, 
Pendampingan Pengembangan Media Pembelajaran Interaktif dengan Program Autolay bagi Mahasiswa

Primadya Anantyarta, Dwi Candra Setiawan

spesialis dan doktor) (Novalita, 2019). Salah satu perguruan tinggi swasta yang terdapat di kota Malang adalah Institut Keguruan dan Ilmu Pendidikan Budi Utomo atau disingkat dengan IKIP Budi Utomo dan disingkat lagi dengan nama IBU. Merupakan salah satu kampus swasta yang memiliki mahasiswa berasal dari seluruh Indonesia bahkan dengan program pertukaran mahasiswa juga terdapat peserta perkuliahan dari luar negeri seperti Jepang, Korea Selatan, Afganistan, Spanyol, Thailand dan lainnya. Mahasiswa yang berasal dari dalam negeri didominasi dari Nusa Tenggara Timur, Kalimantan Barat dan Jawa, tetapi tetap terdapat mahasiswa yang berasal dari Riau, Palembang, Maluku, Sulawesi, Bali bahkan Papua.

Kampus IKIP Budi Utomo terletak di Pusat Kota Malang dengan segala kesibukan mulai dari transportasi, ekonomi, kesehatan dan pendidikan terletak dalam satu tempat. Pada kampus ini terdapat 7 program studi yang semuanya berbasis pendidikan. Program studi yang mencetak sarjana pendidikan tersebut antara lain: Pendidikan Biologi, Pendidikan Matematika, Pendidikan Bahasa dan Sastra Indonesia, Pendidikan Bahasa Inggris, Pendidikan Ekonomi, Pendidikan Sejarah dan Sosiologi, serta Pendidikan Jasmani Kesehatan dan Rekreasi (PJKR). Kurikulum saat ini mengedepankan konsep paperless atau pembelajaran dengan tidak menggunakan kertas sama sekali atau sangat minim. Baik dalam pembelajaran penyampaian, penugasan serta ujian tengah dan akhir semeseter. Paperless merupakan model teknologi dalam pembelajaran yang ramah lingkungan dengan mengurangi penggunaan kertas dan belum banyak diterapkan dalam dunia pendidikan (Susandi, 2018).

Semakin berkembangnya zaman saat ini, proses pembelajaran tentu juga telah memanfaatkan kecanggihan dan modernnya alat yang diciptakan oleh manusia sendiri. Handphone, PC komputer dan laptop menjadi barang sehari-hari yang tidak lepas dari setiap aktivitas manusia. Teknologi yang digunakan dalam pembelajaran karena memiliki kelebihan seperti menyediakan sarana audio, visual, dan gabungan seperti pada komputer (Zabir, 2018). Kemampuan siswa maupun mahasiswa sebagai peserta didik juga harus mengikuti perkembangan alat yang semakin modern tersebut yang digunakan oleh pendidik dalam mengajar. Hal ini sesuai akan sesuai diterapkan dalam pembelajaran di masa pandemi virus covid-19 saat ini, dimana berbagai macam aktivitas sangat dianjurkan untuk dibatasi, termasuk kegiatan pembelajaran.

Kegiatan belajar mengajar sebelum era new normal seperti sekarang ini dapat dilakukan dengan tatap muka secara langsung, dilakukan dalam satu ruangan dan dalam 
satu waktu. Untuk saat ini kegiatan tersebut belum lagi kita laksanakan karena dikhawatirkan memicu penyebaran lebih luas virus yang tidak terlihat oleh mata secara langsung. Pada dasarnya virus juga dipelajari pada pendidikan biologi, namun titik tolak dari pendampingan ini adalah salah satu cara yang dapat kita lakukan melalui bidang pendidikan yaitu dengan berusaha membuat media pembelajaran yang interaktif agar meskipun belajar dengan tidak bertemu secara langsung dalam kelas dan waktu yang sama, baik siswa maupun guru tetap dapat melakukan pembelajaran.

Pembelajaran saat pandemi ini dilakukan secara daring dengan menggunakan zoom meeting atau google meet. Hal ini membantu membatasi tatap muka dalam ruangan sehingga pembelajaran tetap dapat berlangsung. Hal yang dirasakan saat pembelajaran daring baik oleh siswa, mahasiswa ataupun guru dan dosen adalah pembelajaran terfokus pada banyaknya tugas yang harus selesaikan. Pemahaman materi masih kurang dikuasai saat pembelajaran secara online jika dibandingkan belajar secara langsung. Selain itu, banyaknya mahasiswa yang mematikan kamera saat pembelajaran berlangsung sedikit membuat dosen merasa mengajar/berbicara sendiri atau dengan sedikit mahasiswa. Hal ini juga dapat mempengaruhi mood atau motivasi dosen dalam mengajar.

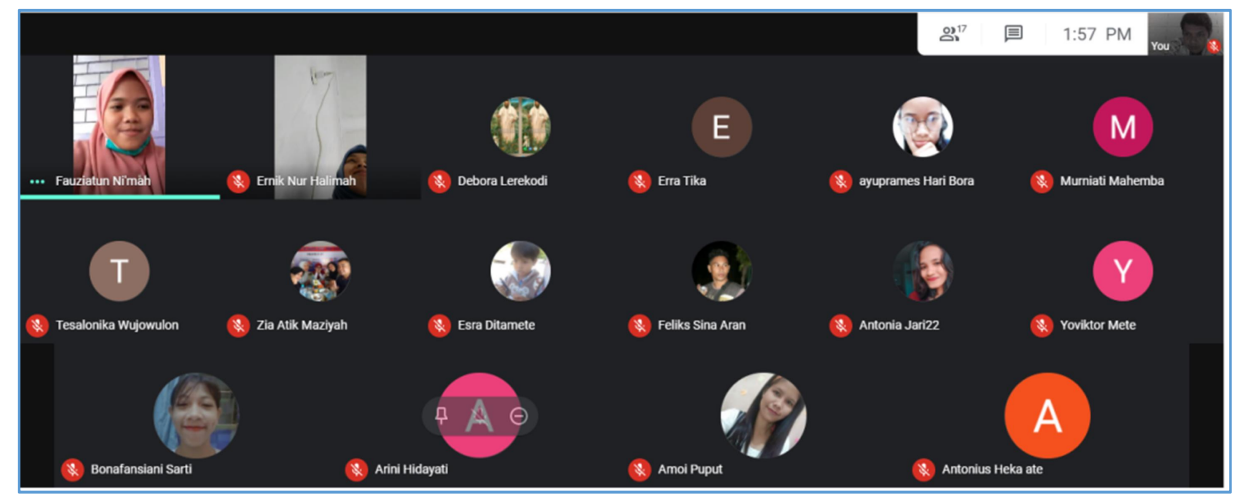

Gambar 1. contoh pembelajaran daring menggunakan google meet

Adanya media pembelajaran interaktif membuat siswa tetap dapat belajar secara mandiri agar tidak tertinggal dalam proses belajar. Motivasi belajar siswa dapat terjaga atau meningkat dengan adanya aktivitas dalam media pembelajaran. Aktivitas dalam media tersebut berupa navigasi halaman, kontrol menu, tombol, link bahkan feedback pada siswa (Surjono Herman Dwi, 2017). Beberapa aktivitas tersebut tersedia dalam aplikasi Autoplay Media Studio yang dapat mengintegrasikan berbagai bentuk file seperti gambar, tulisan, video animasi dan dapat diatur navigasinya melalui tombol atau ikon yang diberikan pengkodean terlebih dahulu (Anantyarta and Sari, 2017); (Anantyarta and Mardiana, 2020). 
Oleh karena itu, diadakannya pendampingan pada mahasiswa calon guru diharapkan dapat melatih mahasiswa lebih lancar dan menguasai dalam mengembangkan media pembelajaran interaktif yang dapat digunakan untuk mengajar saat lulus nanti. Selain itu, dengan pendampingan ini mahasiswa dapat terlatih dalam pengkodean dan menata navigasi serta akan tercipta berbagai variasi tema pembelajaran yang dapat dituangkan dalam media pembelajaran interaktif.

\section{BAHAN DAN METODE}

Pendampingan pelatihan pengembangan atau kebih jelasnya pembuatan media pembelajaran interaktif bagi mahasiswa ini menggunakan sarana berupa ruang kelas serta prasarana berupa PC atau laptop masing-masing mahasiswa serta pendamping dan yang paling utama adalah aplikasi komputer bernama Autoplay Media Studio 8.

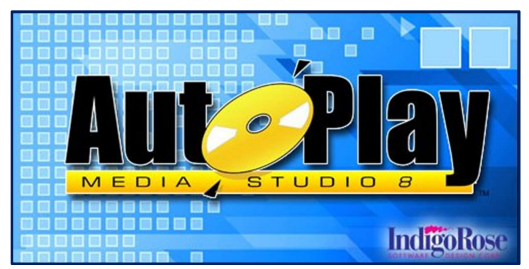

\section{Gambar 2. Tampilan aplikasi computer Autoplay Media Studio 8}

Dalam pendampingan pembuatan atau pengembangan media pembelajaran interaktif ini, menggunakan beberapa langkah dalam metodenya. Untuk metode utama yaitu dilakukan analisis kebutuhan media pembelajaran, analisis kemampuan mahasiswa, pengelompokan mahasiswa (peserta pendampingan), ceramah, simulasi dari dosen sebagai pendamping, praktik langsung bagi peserta, evaluasi dan penyelesaian produk media interkatif. Tempat pelaksanaan pendampingan berada pada kampus IKIP Budi Utomo Malang dimulai dari Bulan Januari hingga Juni 2021. Subjek pendampingan adalah mahasiswa semester 6 yang dipersiapkan untuk melakukan penelitian pengembangan media pembelajaran sebagai tugas akhir atau skripsi.

Secara detail, metode dalam pendampingan ini adalah sebagai berikut:

1. Analisis kebutuhan media pembelajaran

2. Analisis kemampuan mahasiswa

3. Pengelompokan mahasiswa (peserta pendampingan)

4. Ceramah

5. Simulasi dari dosen sebagai pendamping

6. Praktik langsung bagi peserta (Mengembangkan Media) 
7. Evaluasi

8. Penyelesaian produk media interkatif

Secara ringkas, alur metode dalam pendampingan ini disusun dalam diagram berikut:

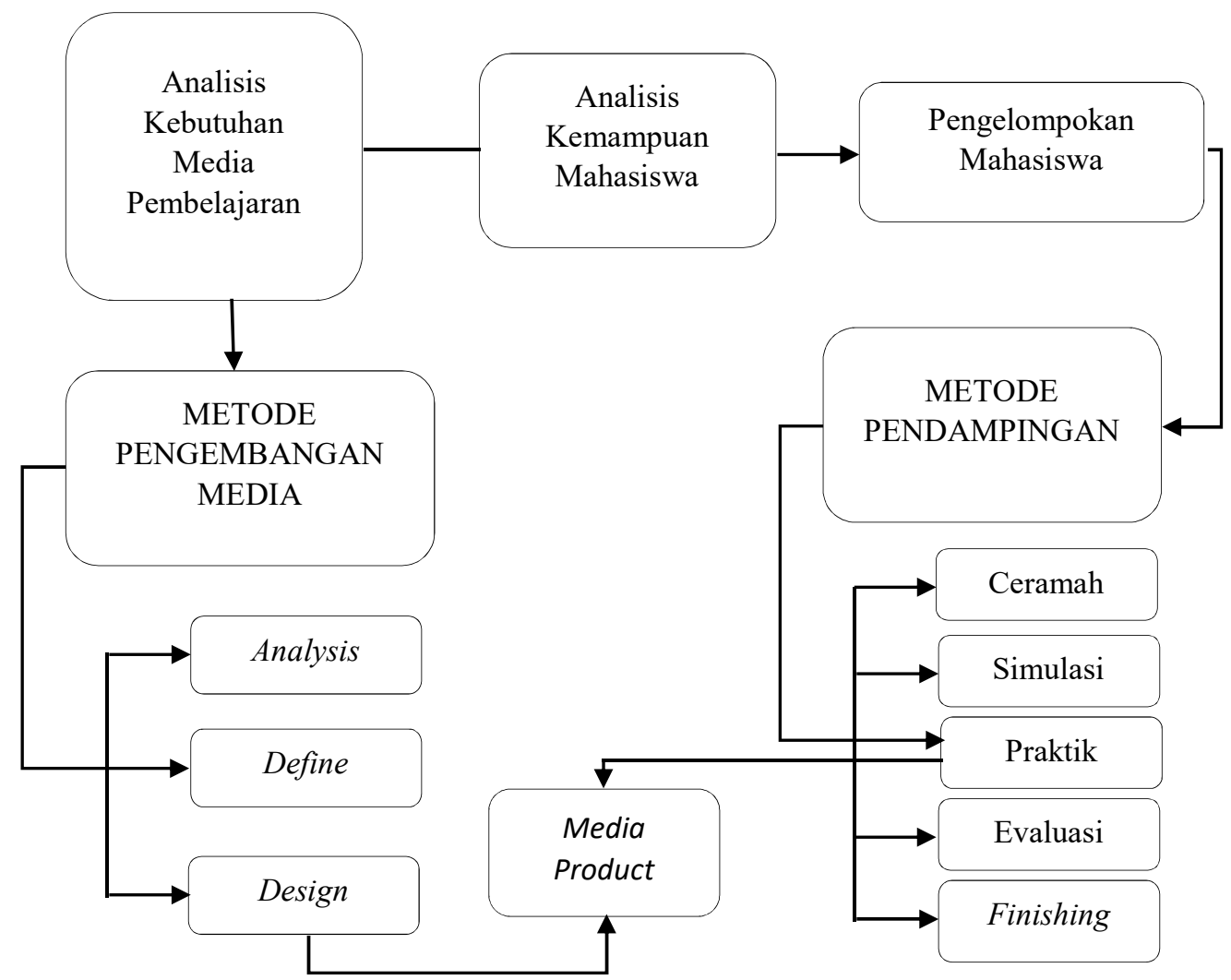

Gambar 3. Alur metode pendampingan pengembangan media pembelajaran interaktif

\section{HASIL DAN PEMBAHASAN}

Berdasarkan hasil selama pendampingan mengenai pengembangan media interaktif media pembelajaran didapatkan hasil sebagai berikut: Pendampingan ini melibatkan mahasiswa sebanyak 10 orang yang terdiri atas 1 mahasiswa dan 9 mahasiswi dengan inisial serta pengelompokan dalam pembuatan tema media sebagaimana pada Tabel 1 .

Tabel 1: Daftar inisial peserta pendampingan, kriteria dan tema media yang dikembangkan

\begin{tabular}{cccc}
\hline No & Inisial Mahasiswa (L/P) & Kriteria Pemahaman & Tema Media Pembelajaran \\
\hline 1. & FN (P) & Baik & Sistem Ekskresi \\
2. & R (P) & Sedang & Bioteknologi \\
3. & I (P) & Baik & Sistem Reproduksi \\
4. & MH (P) & Sedang & Jamur \\
5. & EM (P) & Baik & Sistem Ekskresi + Game Engklek \\
6. & DA (L) & Baik & Sistem Koordinasi \\
7. & MA (P) & Baik & Sistem Indera + Game Congklak \\
8. & HO (P) & Sedang & Sistem Pernapasan \\
9. & LM (P) & Sedang & Sistem Pencernaan \\
10. & RJ (P) & Baik & Sistem Indera + Game Bokah \\
\hline
\end{tabular}

1. Analisis kebutuhan media pembelajaran 
Analisis kebutuhan dilakukan secara interview kepada guru atau dosen yang pernah mengajar masing-masing mahasiswa, baik saat pelaksanaan praktik pengalaman lapangan di sekolah (PPL) atau mewawancarai dosen pengampu yang pernah mengajar di kelas. Berdasarkan hasil tersebut didapatkan bahwa media pembelajaran interaktif sangat dibutuhkan dan penting untuk dikembangkan serta beberapa tema yang bisa dibuat tertera pada Tabel 1.

\section{Analisis kemampuan mahasiswa}

Analisis kemampuan mahasiswa terhadap pemahaman mengenai nama program autoplay serta cara mengoperasikannya didapatkan melalui praktik secara langsung yang diamati saat pelaksanaan perkuliahan pengembangan media pembelajaran pada semester 5, dan didapatkan kriteria mahasiswa termasuk dalam kategori sedang dan baik seperti terlihat pada Tabel 1 .

\section{Pengelompokan mahasiswa (peserta pendampingan)}

Berdasarkan pengelompokan mahasiswa berdasarkan kemampuan mengoperasikan program autoplay dalam mengembangkan media, didapatkan 6 mahasiswa termasuk kategori baik dan 4 mahasiswa termasuk kategori sedang sehingga pengelompokan bersifat tutor sebaya, yaitu mahasiswa dengan kategori baik tergabung dalam 1 kelompok dengan 1 mahasiswa dengan kategori sedang. Sedangkan berdasarkan data kriteria mahasiswa di atas, terdapat 1 kelompok yang sama sama terdiri atas mahasiswa dengan kemampuan baik. Dalam satu kelompok terdapat 2 mahasiswa saja sehingga bisa disebut kelompok kecil yang memungkinkan pendekatan secara pribadi antar mahasiswa dibimbing dosen sehingga lebih cepat memahami dalam pembelajaran/ pendampingan (Rohmayanti, Yulistio and Utomo, 2019).

\section{Ceramah}

Metode ceramah dilakukan secara langsung oleh dosen pendamping mengenai membuka aplikasi, mengenalkan ikon dalam program yang bisa dipakai serta kebutuhan penggunaan materi dan gambar dari internet yang bisa dipakai melengkapi konten materi media pembelajaran yang berasal dari google.com, flaticon.com dan lainnya. Menurut (Adilah, 2017), metode ceramah merupakan metode yang paling mudah digunakan dan dapat menjelaskan materi dalam jumlah besar namun dalam waktu yang singkat. 


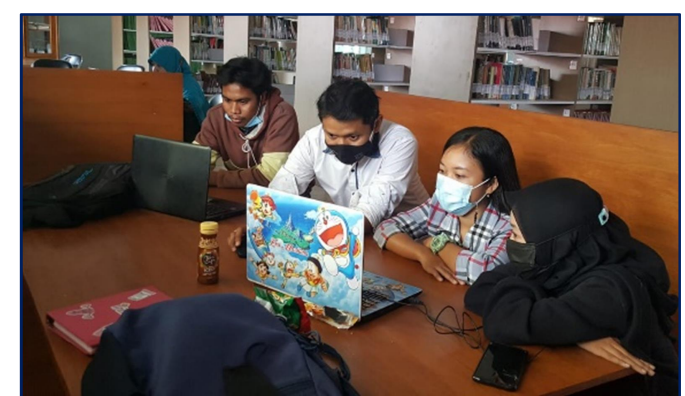

Gambar 4. Kegiatan ceramah dosen dilakukan secara langsung dengan menggunakan aplikasi pada laptop di depan mahasiswa

\section{Simulasi dari dosen sebagai pendamping}

Simulasi merupakan kegiatan yang dilakukan terlebih dahulu oleh dosen pendamping dan kemudian akan diiukuti oleh mahasiswa perserta pendampingan. Hal utama dalam metode simulai adalah ranah keterampilan dalam mempraktikkan teori yang sudah diberikan melalui ceramah, namun pendamping menjelaskan teori tersebut melalui perbuatan tingkah laku bersifat imitasi dalam mempraktikkan membuat media (Handayani, 2017).

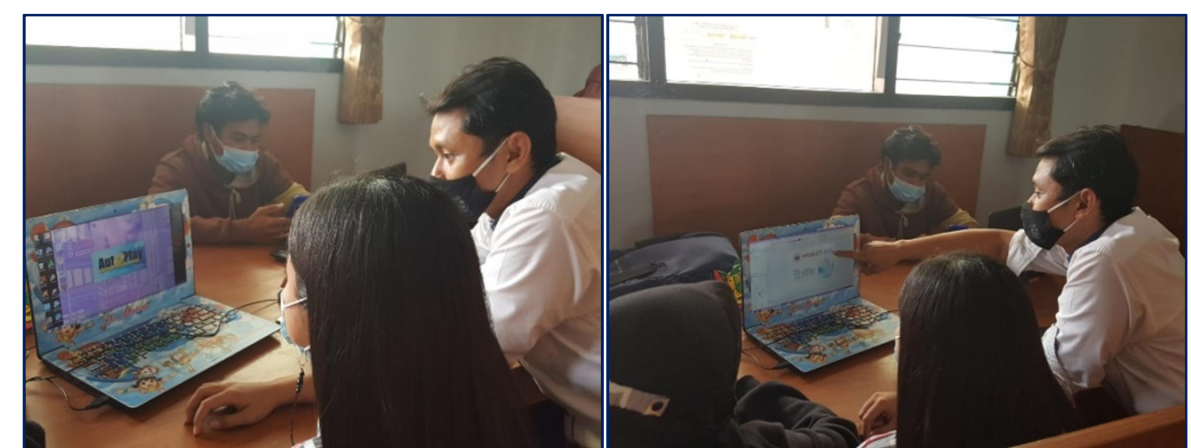

Gambar 5. dosen pendamping mensimulasikan dan memberi contoh pembuatan media dengan aplikasi Autoplay

Dalam metode ini Simulasi secara urut tentang langkah dalam menggunakan Autoplay Media Studio tertera sebagai berikut:

a. Klik icon/logo aplikasi autoplay seperti gambar 6.a maka akan muncul gambar 6.b. yang menuntun pengguna untuk membuat project baru.

b. Klik tulisan "Create a New Project" maka akan muncul gambar 6.c dan kita dapat membuat judul seperti contoh "Media Pembelajaran Interaktif - Bioteknologi”.

c. Selanjutnya beberapa tampilan ikon tombol yang dapat ditambahkan pada media tertera pada gambar 6.d, mulai dari pilihan tombol, insert gambar, insert word, dan lainnya yang terletak pada bagian atas tampilan Autoplay. 

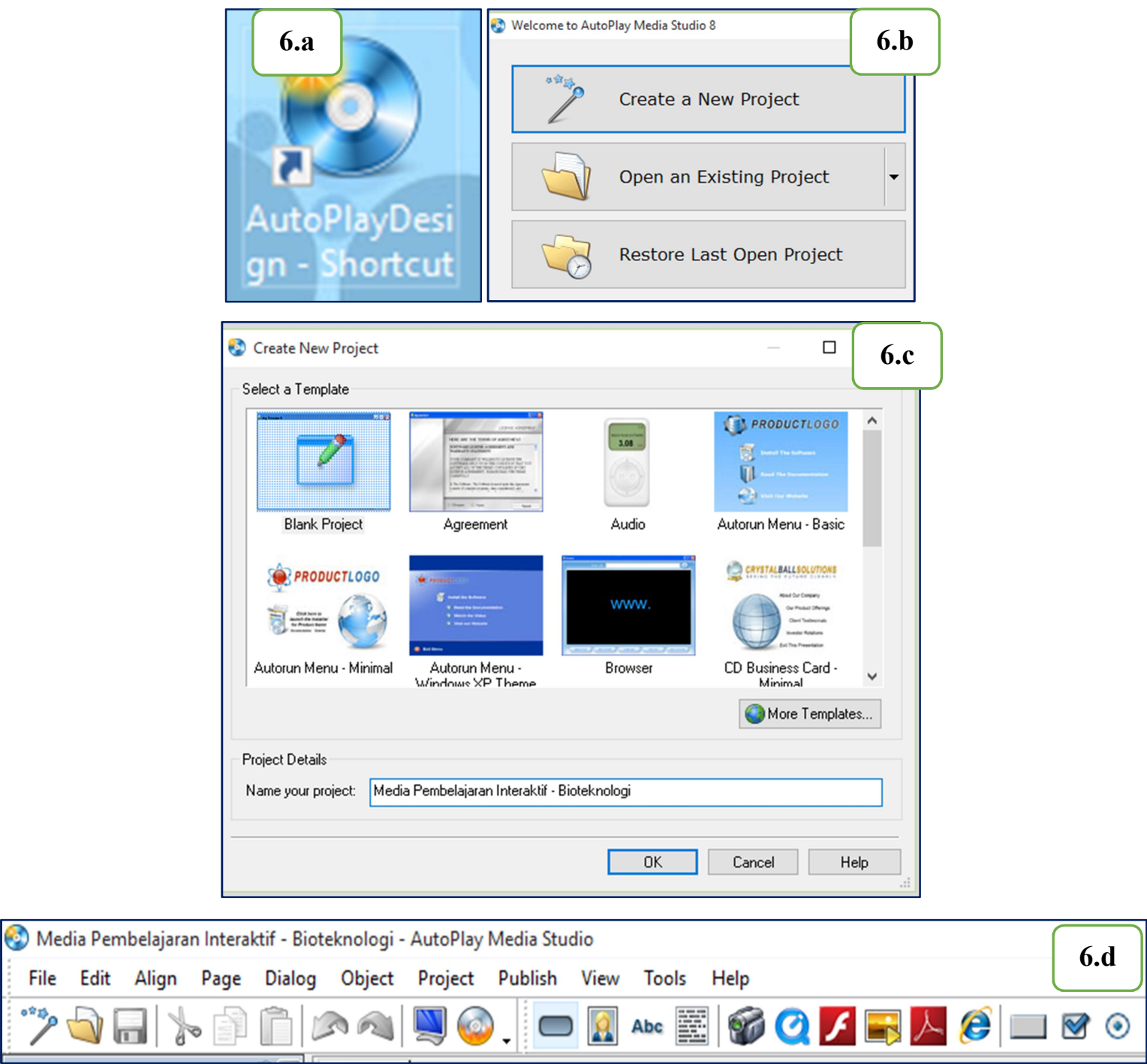

Gambar 6. Macam-macam tampilan saat mengoperasikan Autoplay

\section{Praktik langsung bagi peserta (Mengembangkan Media)}

Kegiatan praktik ini, mahasiswa langsung mengoperasikan program autoplay dimulai dari membuka ikon program autoplay, dan memilih template yang disediakan dalam program untuk memulai membuat tampilan awal. Kegiatan praktik langsung sangat penting bagi siswa karena siswa melakukan sendiri dan memiliki tanggung jawab terhadap apa yang dipelajarinya. Hal ini sesuai dengan pernyataan (Kurniawati, Akbar and Misri, 2015), dimana pada kegiatan ini pendamping menerapkan strategi pembelajaran dimana hanya berperan sebagai fasilitator dan pembelajaran berpusat pada siswa. 


\section{Evaluasi}

Evaluasi merupakan tahap memberikan penilaian terhadap media yang telah dikembangkan oleh mahasiswa, baik dari segi tampilan cover depan, ukuran tulisan judul utama, gambar utama dan pendukung, kelengkapan data penulis/pembuat media serta warna yang digunakan. Berlanjut pada konten yang diawali dengan menu pilihan yang menyajikan berbagai halaman yang berisi penjelasan singkat, penjelasan panjang dan lebar, video pendukung materi, serta soal latihan yang ditambahakan dalam media. Ikon atau tombol yang dipakai dalam media juga harus imbang baik ukuran, warna serta tata letak dalam setiap halaman dan diusahakan tidak mengganggu fokus utama yaitu isi materi dan gambar dalam materi. Evaluasi merupakan kegiatan yang berkaitan dengan pembelajaran dengan tujuan untuk mengetahui perubahan sebelum dan sesudah belajar (L, 2019). Oleh karena itu, dalam kegiatan ini evaluasi juga dilakukan untuk mengetahui perubahan hasil media pembelajaran yang dihasilkan oleh mahasiswa dari hasil pendampingan tersebut.

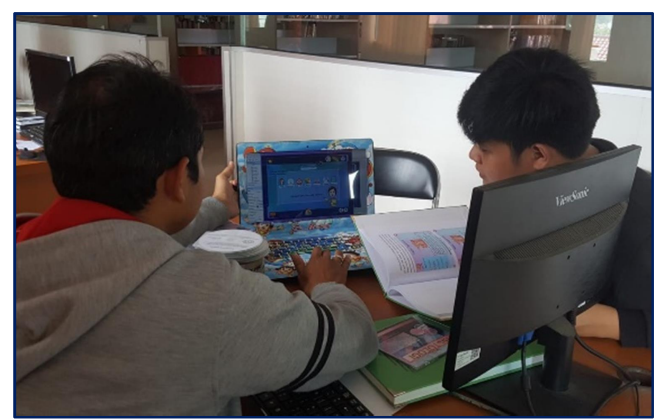

\section{Gambar 7. Dosen pendamping melakukan evaluasi produk media pembelajaran interaktif karya mahasiswa}

Berikut salah satu hasil produk media pembelajaran yang dihasilkan oleh mahasiswa:

1. Bagian cover media pada program Autoplay

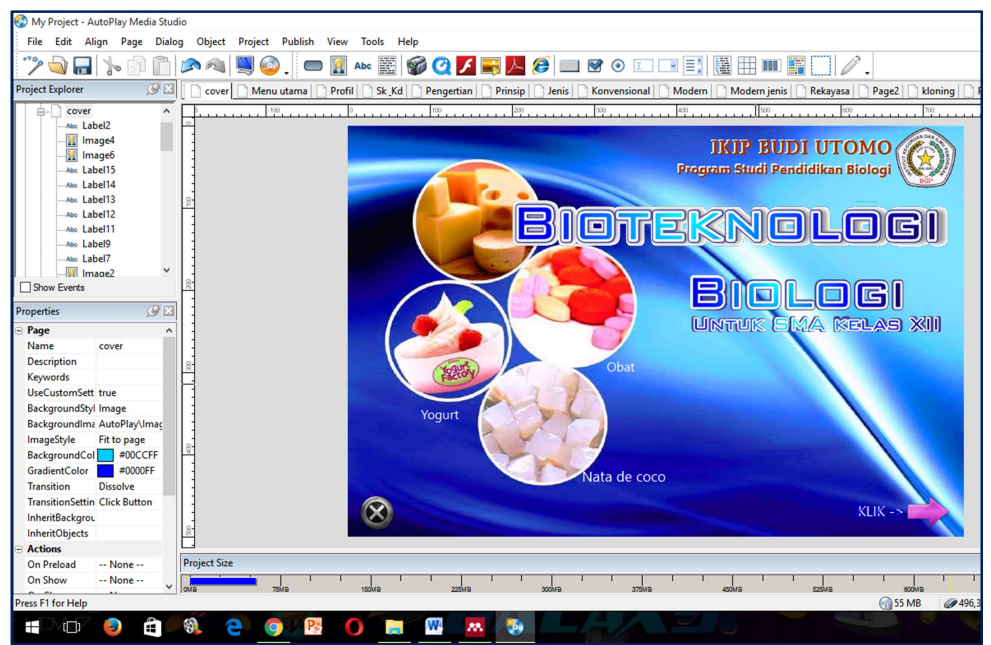

Gambar 8. Tampilan cover yang dibuat oleh mahasiswa dengan Autoplay 
Pada gambar tersebut tertera judul utama yaitu Bioteknologi, yang diperuntukkan bagi siswa kelas XII SMA. Terdap;at 4 gambar dalam lingkaran dengan ukuran lebih besar dari tulisan yang mewakili produk dari bioteknologi baik konvensional maupun modern. Ilustrasi yang dimunculkan pada cover memiliki fungsi sistem tanda secara fisik, eksistensi dan kausal yang berkaitan dengan materi yang dibahas (Wibawa, 2014). Terdapat pula tanda $\mathrm{X}$ dalam lingkaran yang terletak pada bagian kiri bawah yang berfungsi untuk keluar dari aplikasi media dan tanda panah warna ungu di pojok kanan bawah yang berfungsi untuk memulai ke halaman selanjutnya pada media pembelajaran.

2. Menu Utama Media Pembelajaran

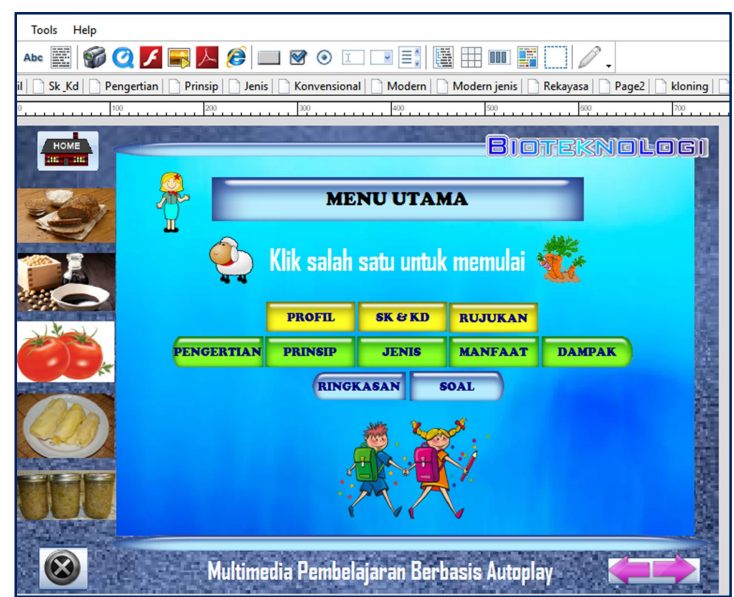

Gambar 9. tampilan menu utama dalam media interaktif hasil mahasiswa

Pada tampilan menu utama merupakan lanjutan dari tombol ungu pada cover sehingga media ini akan bekerja secara interaktif sesuai dengan pengoperasian oleh pengguna media dalam hal ini adalah siswa. Navigasi dan tombol dalam media dibuat agar sesuai fungsinya dan mempermudah siswa dalam belajar dengan menggunakan media pembelajaran (Munir, 2014).

3. Konten materi dalam media pembelajaran

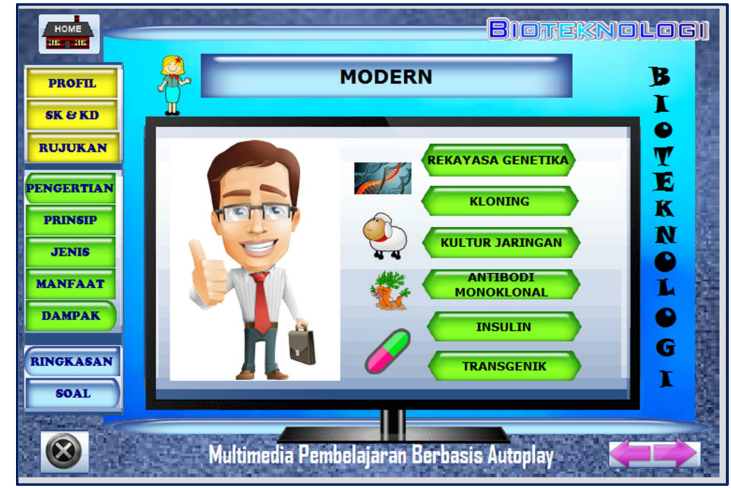

Gambar 10. salah satu konten materi menyediakan pilihan bioteknologi modern yang dapat dipilih sendiri oleh siswa dalam belajar 
Tampilan di atas merupakan salah satu konten dalam media yang menunjukkan macam-macam bioteknologi modern yang dapat dipilih dan dipelajari secara mandiri oleh siswa. Pada tampilan tersebut juga terdapat perbedaan warna antara background dengan tombol agar kontras dan jelas sehingga mudah dalam penggunaan media nantinya oleh siswa. Hal ini sejalan dengan pernyataan (Nurseto, 2012), bahwa penggunaan background yang sederhana namun kontras, tidak terkesan penuh dan mengganggu akan lebih baik digunakan dalam membuat tampilan media.

\section{KESIMPULAN DAN SARAN}

Berdasarkan hasil pendampingan pengembangan media pembelajaran interaktif didapatkan hasil bahwa 6 mahasiswa sudah menguasai aplikasi autoplay dengan kriteria baik dan 4 mahasiswa dengan kriteria sedang; terdapat 10 tema berbeda yang dihasilkan masing-masing mahasiswa peserta pendampingan namun terdapat 2 judul yang sama yaitu sistem ekskresi dan sistem indera. Namun, pada sistem ekskresi terdapat 1 tambahan game dan pada sistem indera masing-masing ditambahkan game yang berbeda.

Untuk pendampingan yang dapat dilakukan dalam kesempatan selanjutnya bisa menggunakan aplikasi komputer yang berbeda dan dengan peserta yang lebih banyak agar pengembangan media pembelajaran interaktif dapat semakin bervariasi.

\section{DAFTAR PUSTAKA}

Adilah, N. (2017) 'Perbedaan Hasil Belajar IPA melalui Penerapan Metode Mind Map dengan Metode Ceramah', Indonesian Journal of Primary Education, 1(1), pp. 98103. doi: 10.17509/ijpe.v1i1.7521.

Anantyarta, P. and Mardiana, E. (2020) 'Learning Media in Pandemic: Autoplay Media Studio Added Stretching Motion to Evaluation Digestive System Subject Media Pembelajaran Masa Pandemi : Autoplay Media Studio ditambah Gerakan Stretching pada Evaluasi Materi Sistem Pencernaan', Bioeducation Journal, 4(2), pp. 47-57. doi: https://doi.org/10.24036/bioedu.v4i2.279.

Anantyarta, P. and Sari, R. L. I. (2017) 'Pengembangan Media Auto Play dengan Metode Means Ends Analysis ( MEA ) pada Matakuliah Genetika', Seminar Pendidikan IPA Pascasarjana UM, 2, pp. 532-538.

Handayani, T. (2017) 'Penerapan Metode Simulasi Pada Materi Pembelajaran Press Conference Guna Meningkatkan Soft Skill Dan Mutu Pembelajaran Di Smkn 3 Bandung Tingkat 11 (Ap4)', Jurnal Penelitian Pendidikan, 17(2), pp. 99-104. doi: 10.17509/jpp.v17i2.8243.

Kurniawati, L., Akbar, R. O. and Misri, M. A. (2015) 'Pengaruh Penerapan Metode Pembelajaran Praktikum Terhadap Keterampilan Berpikir Kritis Matematika Siswa Kelas VIII SMP N 3 Sumber Kabupaten Cirebon', Eduma: Mathematics Education Learning and Teaching, 4 (2)(2), pp. 62-74. Available at: https://media.neliti.com/media/publications/69339-ID-pengaruh-penerapan-metode- 
pembelajaran-p.pdf.

L, I. (2019) 'Evaluasi dalam Proses Pembelajaran', ADAARA: Jurnal Manajemen Pendidikan Islamendidikan Islam, 9(2), pp. 920-935. Available at: https://jurnal.iainbone.ac.id/index.php/adara/article/download/427/352.

Munir, M. (2014) 'Pengembangan Media Pembelajaran Interaktif Kompetensi Dasar Register Berbasis Inkuiri Terbimbing', Jurnal Pendidikan Teknologi dan Kejuruan, 22(2), pp. 184-190. Available at: https://media.neliti.com/media/publications/163614-ID-pengembangan-mediapembelajaran-interakt.pdf.

Novalita, R. (2019) 'Perbandingan Pendidikan Negara Belgia Dengan Negara Indonesia', Jurnal Spasial, 4(3), pp. 75-84. doi: 10.22202/js.v4i3.2395.

Nurseto, T. (2012) 'Membuat Media Pembelajaran yang Menarik', Jurnal Ekonomi dan Pendidikan, 8(1), pp. 19-35. doi: 10.21831/jep.v8i1.706.

Rohmayanti, F., Yulistio, D. and Utomo, P. (2019) 'Pelaksanaan Pembelajaran Kelompok Kecil Dan Perorangan Pada Mata Pelajaran Bahasa Indonesia Siswa Kelas X Di Sma Negeri 8 Kota Bengkulu', Jurnal Ilmiah KORPUS, 3(1), pp. 21-32. doi: 10.33369/jik.v3i1.7343.

Surjono Herman Dwi (2017) Multimedia Pembelajaran Interaktif: Konsep dan Pengembangan, UNY Press. Available at: https://www.researchgate.net/publication/332444168_Multimedia_Pembelajaran_Int eraktif_Konsep_dan_Pengembangan/link/5cb5d017a $\overline{6}$ fdcc1d49985408/download.

Susandi (2018) 'Pemutakhiran Pembelajaran Berbasis Paperless di Program Studi Pendidikan Bahasa dan Sastra Indonesia', ALFABETA, 1(1), pp. 15-27. Available at: http://ejurnal.budiutomomalang.ac.id/index.php/alfabeta/article/view/203.

Wibawa, M. (2014) 'Analisis Kualitas Desain Sampul Buku Sekolah Elektronik (BSE) Mata Pelajaran Seni Budaya', Philpaper. Available at: https://philpapers.org/rec/WIBAKD.

Zabir, A. (2018) 'Pengaruh Pemanfaatan Teknologi Pembelajaran Terhadap Motivasi Belajar Siswa SMPN 1 Lanrisang Kabupaten Pinrang', Jurnal Azhari, 1(1), pp. 1-10. Available at: http://eprints.unm.ac.id/9823/1/Jurnal azhari.pdf. 